\title{
Encapsulation of $\alpha$-amylase into starch-based biomaterials: An enzymatic approach to tailor their degradation rate
}

\author{
Helena S. Azevedo*, Rui L. Reis \\ 3B's Research Group - Biomaterials, Biodegradables and Biomimetics, University of Minho, Headquarters of the European Institute of \\ Excellence on Tissue Engineering and Regenerative Medicine, AvePark, 4806-909 Taipas, Guimarães, Portugal \\ IBB - Institute for Biotechnology and Bioengineering, PT Government Associated Laboratory, Guimarães, Portugal
}

Received 4 October 2008; received in revised form 16 March 2009; accepted 30 April 2009

Available online 7 May 2009

\begin{abstract}
This paper reports the effect of $\alpha$-amylase encapsulation on the degradation rate of a starch-based biomaterial. The encapsulation method consisted in mixing a thermostable $\alpha$-amylase with a blend of corn starch and polycaprolactone (SPCL), which were processed by compression moulding to produce circular disks. The presence of water was avoided to keep the water activity low and consequently to minimize the enzyme activity during the encapsulation process. No degradation of the starch matrix occurred during processing and storage (the encapsulated enzyme remained inactive due to the absence of water), since no significant amount of reducing sugars was detected in solution. After the encapsulation process, the released enzyme activity from the SPCL disks after 28 days was found to be $40 \%$ comparatively to the free enzyme (unprocessed). Degradation studies on SPCL disks, with $\alpha$-amylase encapsulated or free in solution, showed no significant differences on the degradation behaviour between both conditions. This indicates that $\alpha$-amylase enzyme was successfully encapsulated with almost full retention of its enzymatic activity and the encapsulation of $\alpha$-amylase clearly accelerates the degradation rate of the SPCL disks, when compared with the enzyme-free disks. The results obtained in this work show that degradation kinetics of the starch polymer can be controlled by the amount of encapsulated $\alpha$-amylase into the matrix.
\end{abstract}

(C) 2009 Acta Materialia Inc. Published by Elsevier Ltd. All rights reserved.

Keywords: Starch-based biomaterials; Controlled degradation rate; Thermostable $\alpha$-amylase; Encapsulation; Enzyme activity

\section{Introduction}

The demands for biomaterials with controlled, predictable degradation kinetics includes a wide range of biomedical applications, such as resorbable surgical sutures, matrices for the controlled release of drugs and scaffolds for tissue engineering [1-4]. In fact, the performance of many biomaterials depends largely on their degradation behaviour since the degradation process may affect a range

\footnotetext{
Corresponding author. Address: 3B's Research Group - Biomaterials, Biodegradables and Biomimetics, University of Minho, Headquarters of the European Institute of Excellence on Tissue Engineering and Regenerative Medicine, AvePark, 4806-909 Taipas, Guimarães, Portugal. Tel.: +351 253 510907; fax: +351253510909.

E-mail address: hazevedo@dep.uminho.pt (H.S. Azevedo).
}

of events, such as cell growth, tissue regeneration, drug release, host response and material function.

Biodegradable polymers are materials with the ability of functioning for a temporary period and subsequently degrade in physiological conditions, under a controlled mechanism, into products easily eliminated in the body's metabolic pathways.

Several strategies have been developed to obtain biomaterials with a controlled degradation rate. Those have been based on molecular design principles, such as the introduction of hydrolysable bonds into polymer backbones [5], copolymerization and blending techniques [6], crosslinking $[7,8]$ and surface modification methods $[9,10]$, and inclusion of certain additives [11-13] into polymeric matrices (e.g. excipients, drugs, salts, etc.).

An interesting approach has been the development of polymeric systems with a self-regulated degradation 
mechanism. In these systems, the degradation process is initiated and/or controlled under certain environment conditions or in response to cell activities $[3,14,15]$. For instance, Hubbell and co-workers [16-18] developed a novel class of hydrogels that are sensitive to the activity of cell-associated proteases. This cell-mediated degradation approach consists in the inclusion of enzymatic recognition sites into polymer backbones to make the material sensitive to the feedback provided by the cells involved in the healing response. In this way, the materials will degrade in response to cellular activities and the tissues may determine the degradation rate of the materials rather than the calendar.

Materials to be used in some applications, such as hardtissue replacement, must combine adequate mechanical properties with controlled biodegradability. The material should degrade while maintaining a specified minimum mechanical strength to support the formation of new tissue. It may be difficult to achieve the desired combination of degradation and physical properties in a single material. In this context, enzyme encapsulation technology can be used to incorporate hydrolytic enzymes into the polymeric matrices and then provide systems with controlled degradation. Controlled degradation by enzymatic means presents several advantages considering the high specificity of enzymes for their substrates and also because enzyme activity can be regulated by environmental conditions (e.g. $\mathrm{pH}$, temperature, the presence of certain substances, like metal ions) [19]. In addition, the degradation kinetics can be adjusted by the amount of encapsulated enzyme into the matrix. For instance, Goldbart et al. [14] developed an enzymatically controlled responsive drug delivery system consisting of a starch-based tablet incorporating a nonactive $\alpha$-amylase and a protein. The enzyme reactivation was made by the presence of calcium ions (which is known to be essential for enzyme's tertiary structure and catalytic activity) from the medium, which causes the tablet degradation and the concomitant release of the protein.

A basic requirement in enzyme encapsulation technology is that the integrity of the enzyme structure must be maintained during the encapsulation process. This is often a difficult challenge as most proteins are dependent on a threedimensional conformation for their bioactivity and that conformation can be easily compromised. For instance, most of the polymers that are used in biomedical applications are not soluble in water and consequently the protein is exposed to an organic solvent during the encapsulation step. Examples of other stress conditions associated with the manufacture of medical devices, and that may compromise protein integrity, are the high shear forces used during extrusion processes or to form droplets of the polymer solution in a continuous phase, exposure to polymer reactions, high temperature and adverse $\mathrm{pH}$ values [20].

Starch is a fully biodegradable material that is readily available and can easily be modified, therefore constituting a good material to produce encapsulation matrices [2124]. Several starch-based formulations have been prepared containing encapsulated $\alpha$-amylase to develop enzymati- cally controlled drug delivery systems $[14,21,24,25]$. The methods used for the preparation of the tablets have been based mainly on mechanical compression [14,24]. Physical compression does not allow good adhesion to be obtained between components, leading to the formation of tablets without enough mechanical integrity. Starch has thus been blended with synthetic polymers (polycaprolactone, poly(lactic acid), poly(butylene succinate adipate, poly(ethylene-co-vinyl alcohol), etc.) to improve its weakness and obtain better mechanical properties [26-31]. Starch-based polymers have been studied and proposed as potential materials to be used in several biomedical applications [32-38], namely as carriers for drug delivery [36,37], hydrogels and partially degradable bone cements [37,39], and porous structures to be used as scaffolds in bone tissue engineering $[33,35]$. The susceptibility of these starch polymeric blends to enzymatic degradation has also been reported $[40,41]$.

The processing conditions of thermoplastics, however, does not allow the incorporation of biomolecules like proteins or enzymes during processing, since the high temperatures used during melt-based processes can cause irreversible changes to the protein structure, leading to its denaturation. The use of enzymes with high heat stability can overcome this obstacle and constitute a good alternative that can efficiently encapsulate enzymes by melting techniques.

In this work, a thermostable $\alpha$-amylase was encapsulated in a starch matrix (processed by compression moulding) with the aim of tailoring its degradation rate.

\section{Materials and methods}

\subsection{Materials}

The material used in this work was a commercially available thermoplastic starch-based polymer ( $Z$ grade MATER-BI ${ }^{\circledR}$, ZI01U), supplied by Novamont S.P.A. (Novara, Italy) in granular form, containing starch, poly( $\epsilon$-caprolactone) (PCL) and plasticizers (glycerol) [42]. This material is described in several patents [31,42-45], and is based on native maize starch and PCL with a molecular weight of 118,000 [42]. The properties and characteristics of the starch/PCL blend (SPCL) can be found in previous publications $[46,47]$. Soluble potato starch for measuring $\alpha$-amylase activity was obtained from SigmaAldrich Inc. (St. Louis, MO, USA).

The encapsulant enzyme was a thermostable $\alpha$-amylase supplied in a liquid formulation (SPEZYME ${ }^{\circledR}$ FRED, Genencor International Inc., Rochester, NY, USA) produced by a genetically modified strain of Bacillus licheniformis.

\subsection{Preparation of starch-based matrices: the encapsulation method}

Prior to use, the enzyme was first lyophilized to obtain the enzyme in powder form. Then the enzyme was mixed with the polymer powder (previously milled in a high speed milling equipment) at different weight percentages $(0.5 \%$ and 


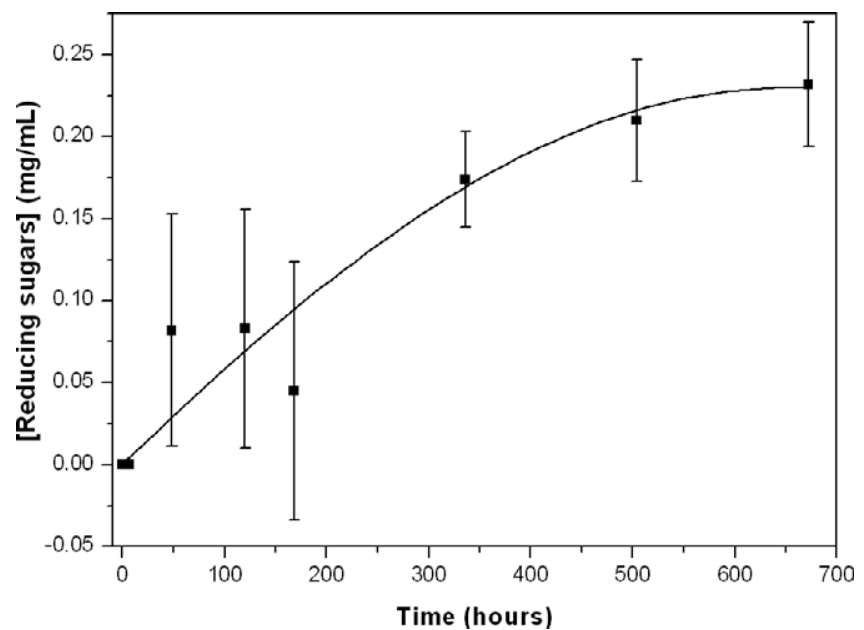

Fig. 1. Concentration of reducing sugars in solution after immersion of SPCL disks $(0.5 \%$ encapsulated $\alpha$-amylase) in PBS ( $\mathrm{pH} 7.4)$ at $4{ }^{\circ} \mathrm{C}$ for different periods of time. The data points in the figure represent the mean of three replicates and error bars the standard deviation.
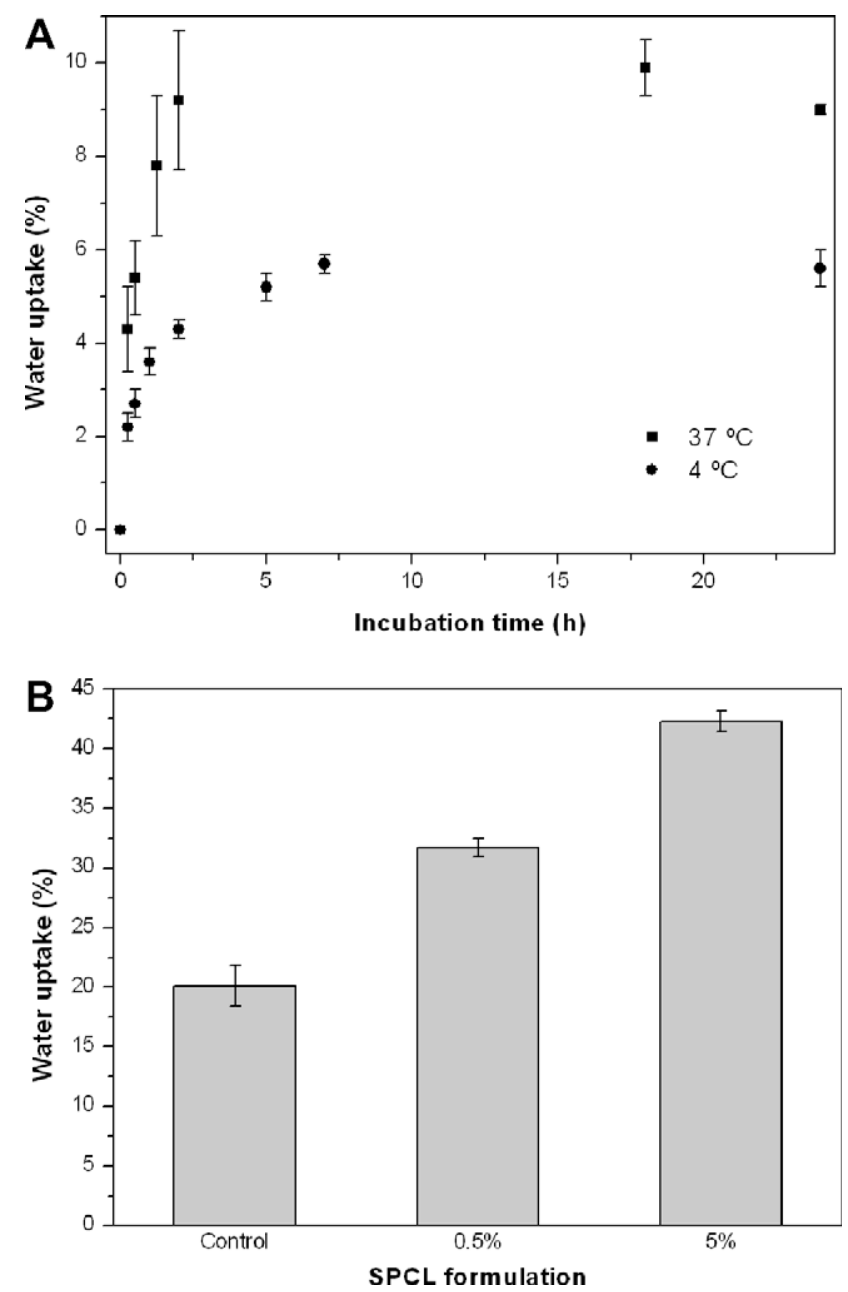

Fig. 2. (A) Evolution of water uptake of SPCL disks (controls) in PBS (pH 7.4) at 4 and $37^{\circ} \mathrm{C}$ for $24 \mathrm{~h}$. (B) Water uptake of SPCL disks (controls and encapsulated with $0.5 \%$ and $5 \%$ of $\alpha$-amylase) after incubation in PBS (pH 7.4) at $37^{\circ} \mathrm{C}$ for 1 week. The data points in the figures represent the mean of four replicates and error bars the standard deviation.
$5 \%$, relative to the polymer mass) and processed by compression moulding $\left(P=4 \mathrm{~kg} \mathrm{~cm}^{-2}, T=90^{\circ} \mathrm{C}, 20 \mathrm{~min}\right)$ in a hydraulic press to prepare disks of about $0.25 \mathrm{~g}$ (diameter $=1 \mathrm{~cm}$, thickness $=2 \mathrm{~mm}$ ). A control, without enzyme, was also prepared. The disks were stored in closed containers at room temperature (away from excess of heat and moisture) until further use.

\subsection{Water uptake studies}

To determine the water uptake of the starch-based matrices, enzyme-free disks (control) were immersed in $2.5 \mathrm{ml}$ of phosphate-buffered saline (PBS) solution $(0.01 \mathrm{M}, \mathrm{pH} 7.4)$ and incubated at 4 and $37^{\circ} \mathrm{C}$. The water uptake for loaded disks (with $0.5 \%$ enzyme) was also determined at $4{ }^{\circ} \mathrm{C}$. The disks were weighed periodically to calculate the percentage of water uptake. Before measuring the wet weight, any surface water was removed by placing the disks between two filter papers.
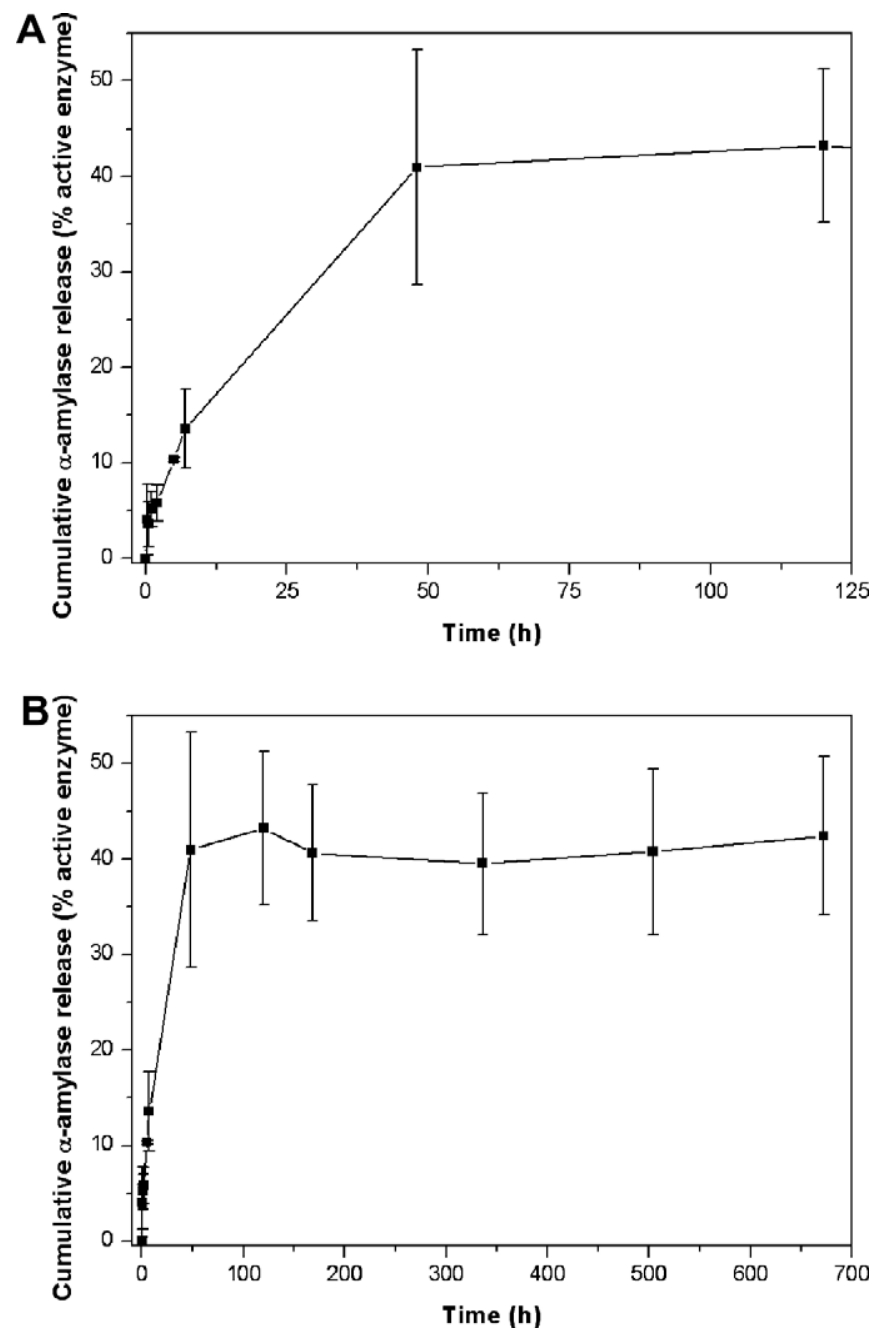

Fig. 3. $\alpha$-Amylase release ( $\%$ active enzyme) from the SPCL disks loaded with $0.5 \% \alpha$-amylase in PBS (pH 7.4) at $4{ }^{\circ} \mathrm{C}$ (A) (see Section 2 for details). (B) shows the $\alpha$-amylase release for a period of 4 weeks $(672 \mathrm{~h}$ ). The data points in the figure represent the mean of three replicates and error bars the standard deviation. 


\subsection{Enzyme release studies}

Enzyme release from the starch-based matrices was determined by placing the SPCL disks, containing $0.5 \%$ of encapsulated $\alpha$-amylase, in individual tubes containing $2.5 \mathrm{ml}$ of PBS (0.01 M, pH 7.4) solution at $4{ }^{\circ} \mathrm{C}$ to minimize enzyme activity (matrix degradation and consequently release of sugars during the release experiments). Periodically, $0.5 \mathrm{ml}$ aliquots were collected from the release medium and replaced with an equal volume of fresh buffer. The activity of released $\alpha$-amylase was determined by incubating $250 \mu \mathrm{l}$ of appropriately diluted release medium with $1 \mathrm{ml}$ of substrate solution $(1 \% \mathrm{w} / \mathrm{v}$ of a soluble potato starch in $0.01 \mathrm{M}$ of $\mathrm{PBS}, \mathrm{pH} 7.4)$ at $37^{\circ} \mathrm{C}$ under constant agitation in a shaking water bath $(100 \mathrm{rpm})$ for $10 \mathrm{~min}$. The concentration of reducing sugars in the solution was quantified using the dinitrosalicylic acid (DNS) method [48] in a microplate reader (Synergy HT, BIO-TEK Instruments, Inc., Winooski, Vermont, USA) at $540 \mathrm{~nm}$ and using a standard curve of glucose. $\alpha$-Amylase activity was calculated in terms of $\mathrm{U} \mathrm{ml}^{-1}$ ( $1 \mathrm{U}$ corresponds to $1 \mu \mathrm{mol}$ of product formed (reducing sugars as glucose) per min). The cumulative activity of enzyme released from the disks was calculated as the percentage of activity that was mea-
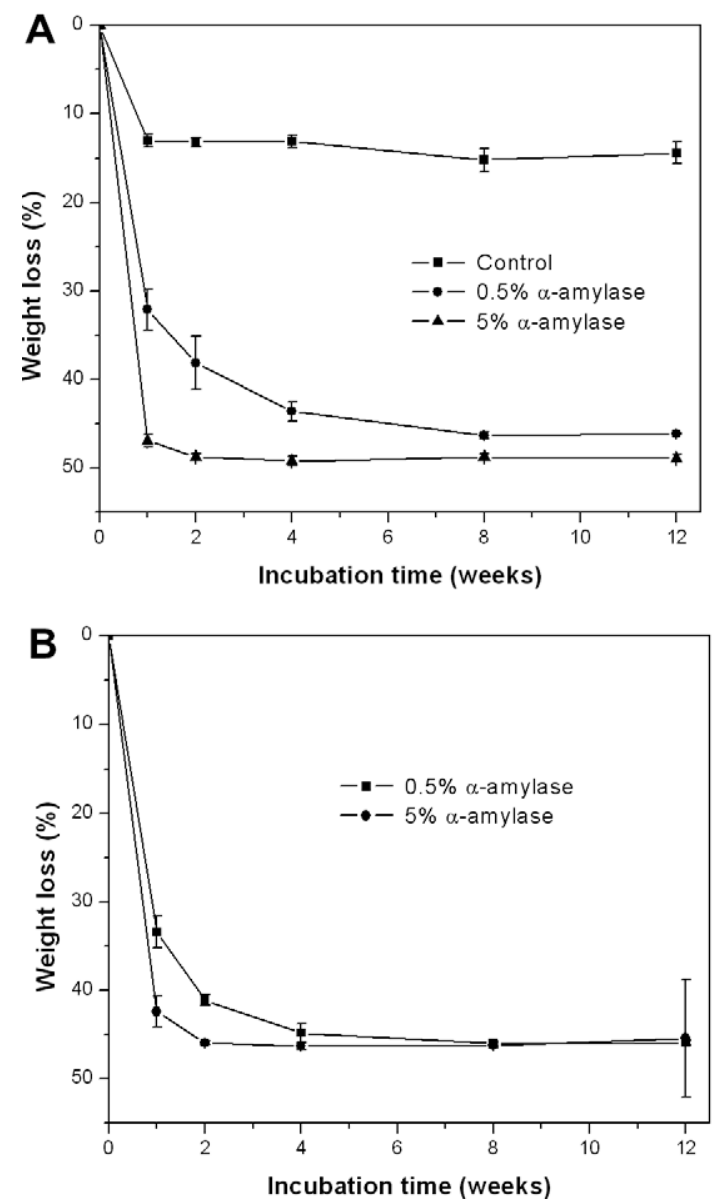

sured using fresh enzyme solution at a concentration equivalent to that which would have been obtained if the encapsulated enzyme was completely released (100\%).

\subsection{Evaluation of the degradation profile of starch-based matrix with encapsulated and free $\alpha$-amylase}

The processed disks were placed in $15 \mathrm{ml}$ tubes containing $2.5 \mathrm{ml}$ of PBS solution (0.01 M, pH 7.4) and incubated at $37^{\circ} \mathrm{C}$ for different periods of time under static conditions (studies with encapsulated enzyme). After this period, the samples were washed thoroughly with distilled water, dried at room temperature and stored in a desiccator for further analysis.

To compare the effect of the encapsulation method on the enzyme activity, another set of experiments was performed using the same amount of encapsulated enzyme dissolved in the buffer solution (studies with free enzyme). The same experimental procedure was followed as described for the studies with encapsulated enzyme.

Matrix degradation was assessed by determination of weight loss and by measuring the concentration of reducing sugars released into the solution as a result of starch hydrolysis by $\alpha$-amylase. The concentration of reducing sugars in
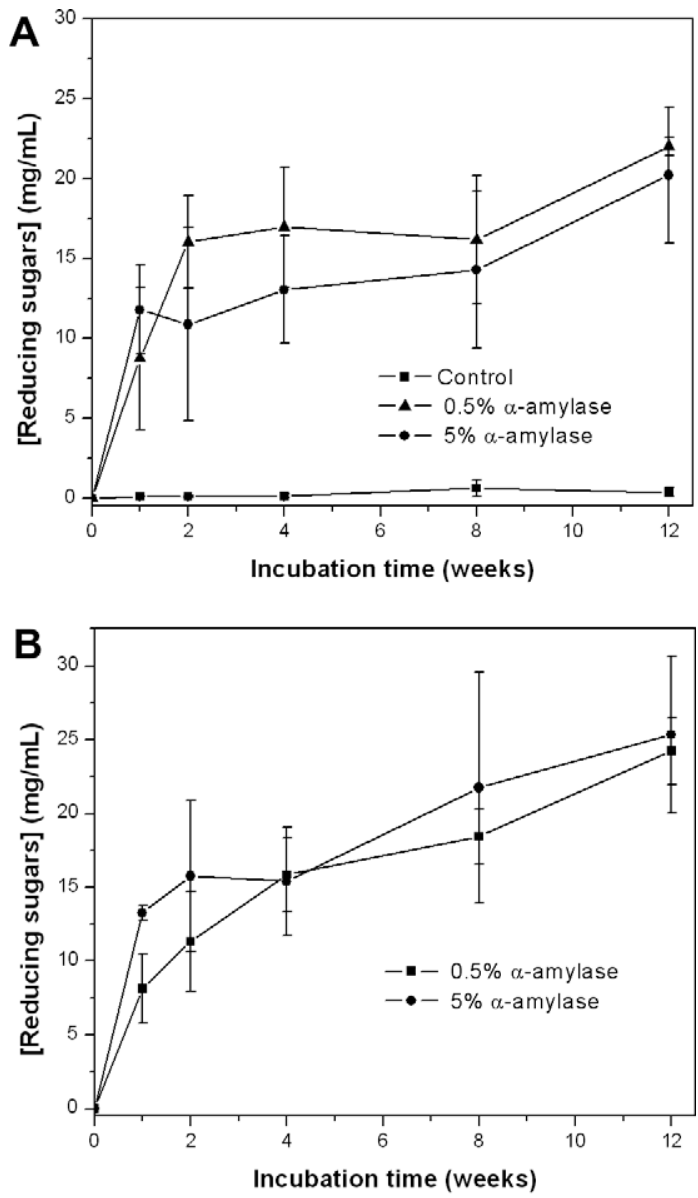

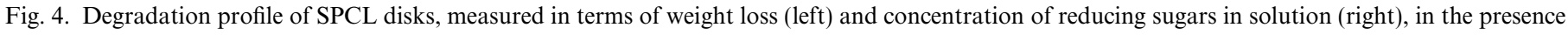

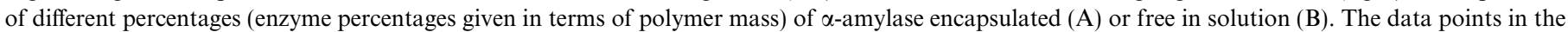
figure represent the mean of four replicates and error bars the standard deviation. 
solution was measured by the DNS method, as described previously. The morphology of the sample surface and interior, before and after degradation, was examined for all the studied conditions by scanning electron microscopy (SEM; Leica Cambridge S360, UK). Changes within the material were analysed by observing the sample cross-section obtained by freeze-fracturing in liquid nitrogen. Prior to SEM observations, the samples were gold sputtered in a Sputter Coater SC502 (Fisons Instruments, UK).

\section{Results}

\subsection{Encapsulation method}

Enzyme encapsulation was performed by a thermomechanical process (compression moulding) at $90{ }^{\circ} \mathrm{C}$. Analysing the results shown in Fig. 1, it can be seen that no noticeable amount of reducing sugars was detected in solution during 28 days (4 weeks) of immersion of the SPCL disks loaded with $\alpha$-amylase $(0.5 \%)$ in PBS at $4{ }^{\circ} \mathrm{C}$, especially when compared with the amount of sugars produced under the same conditions but at higher temperature
(Fig. 4(A)). For instance, at $37^{\circ} \mathrm{C}$, the amount of reducing sugars found in solution after 1 week was $8.748 \pm 4.465$ $\mathrm{mg} \mathrm{ml}{ }^{-1}$, while at $4{ }^{\circ} \mathrm{C}$ the highest concentration of sugars detected in solution was $0.232 \pm 0.038 \mathrm{mg} \mathrm{ml}^{-1}$, and this only after 4 weeks of incubation. These results show that at $4{ }^{\circ} \mathrm{C}$ the enzyme is not capable of performing any catalytic activity, and this lack of catalytic activity is probably due to the low temperature. On the other hand, the absence of sugars in the solution also indicates that during processing there was no hydrolysis of the starch matrix.

\subsection{Water uptake studies}

The water uptake of control disks in PBS at 4 and $37{ }^{\circ} \mathrm{C}$ is presented in Fig. 2A. Water uptake of SPCL disks depends on the temperature, and reaches equilibrium within $2-5 \mathrm{~h}$. In most polymers, water uptake increases with increased temperatures [49]. The higher water uptake at $37^{\circ} \mathrm{C}$ may be due to the temperature-dependent behaviour of the polymers. These differences in water uptake behaviour of the samples at 4 and $37^{\circ} \mathrm{C}$ are expected to influence the release of the enzyme [49] from the SPCL
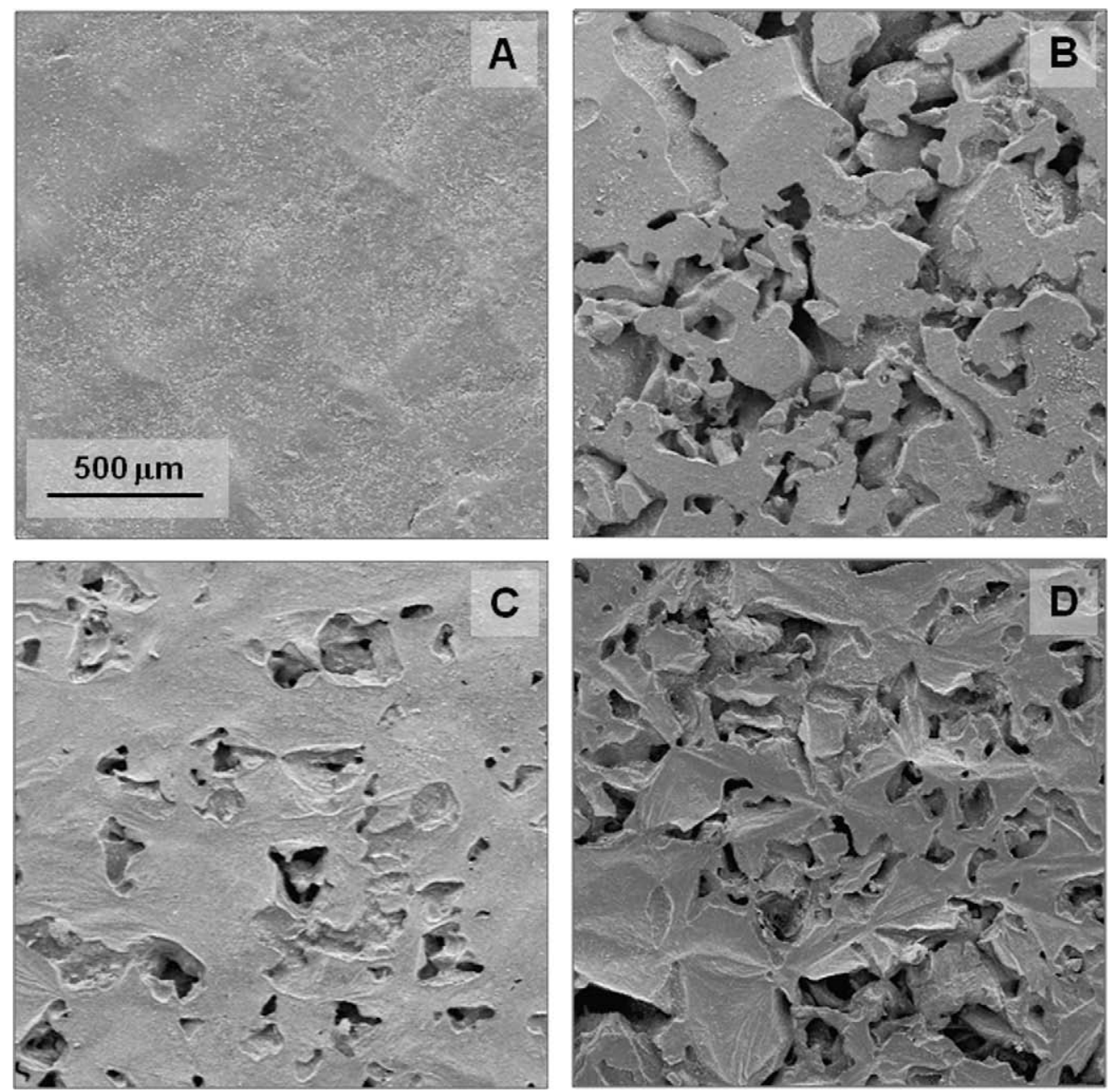

Fig. 5. SEM micrographs of the surface of SPCL disks before (A) and after 4 weeks of degradation in PBS (pH 7.4$)$ at $37{ }^{\circ} \mathrm{C}$. Control (B), with $0.5 \%(\mathrm{C})$ and $5 \%(\mathrm{D})$ encapsulated $\alpha$-amylase. 
disks (Fig. 3). The effect of encapsulated enzyme on the water uptake of the SPCL disks was examined at $4{ }^{\circ} \mathrm{C}$ and is shown in Fig. S1 (Supplementary information). It can be seen that the loaded disks absorb slightly more water than the control samples.

Fig. 2(B) shows the water uptake of SPCL disks after 1 week of incubation in PBS at $37^{\circ} \mathrm{C}$, in which higher values of water uptake are observed. During this incubation period, there is already evidence of matrix degradation (Figs. 4 and 6), the degradation effects being more evident for the samples with the encapsulated enzyme. Internal hydrolysis of the disk will cause pores to form and consequently increase the matrix permeability, leading to faster water penetration.

\subsection{Enzyme release studies}

To assess the enzyme release from the SPCL disks, release experiments were performed at $4{ }^{\circ} \mathrm{C}$ to avoid matrix degradation and consequently the accumulation of reduc- ing sugars in the medium. The activity of the released enzyme was then measured and given as a percentage of the active enzyme (Fig. 3). After immersion in PBS, the enzyme starts to be released as a result of enzyme dissolution that is present at the outermost layer, causing the formation of channels through which water may further penetrate. The enzyme activity reaches a plateau of $40 \%$ of its original activity (unprocessed enzyme) by about $48 \mathrm{~h}$, after which no further increase is observed. These results show that the released enzyme is active but that incomplete release and/or loss of partial activity might have occurred, since the released enzyme did not reach $100 \%$ of the original activity even after 28 days.

\subsection{Evaluation of the degradation profile of the starch-based matrix with encapsulated and free $\alpha$-amylase}

Fig. 4 shows the degradation behaviour of SPCL disks at $\mathrm{pH} 7.4$ in the presence of $\alpha$-amylase, encapsulated in the polymer matrix and free in solution, in terms of weight
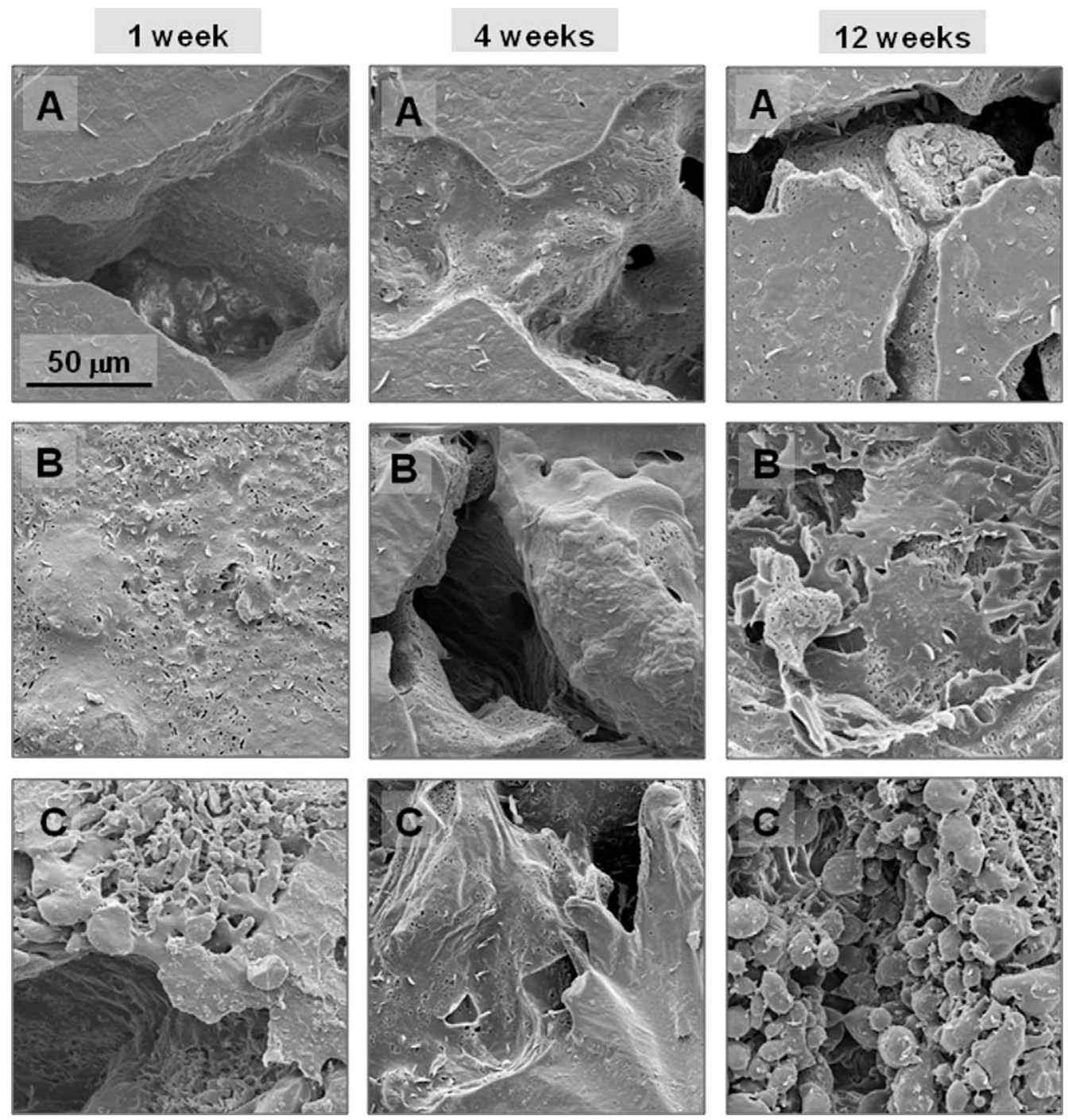

Fig. 6. SEM micrographs of the surface of SPCL disks showing the sample morphology in more detail (micrographs at higher magnifications) after degradation for 1, 4 and 12 weeks in PBS (pH 7.4) at $37^{\circ} \mathrm{C}$. Control (A), with $0.5 \%$ (B) and $5 \%$ (C) encapsulated $\alpha$-amylase. 
loss and concentration of reducing sugars. The control sample exhibits a significant weight loss (about 13\%) during the first week, but the sample mass tends to remain almost constant in the following weeks. The rapid weight loss of the control in the first week is related to the leaching out of plasticizers (glycerol) used in the blend formulation [40], since no noticeable amounts of sugars were detected in solution for the control samples (Fig. 4(A)). With $5 \%$ of encapsulated $\alpha$-amylase, there is a significant percentage of weight loss in the first week, with almost all the starch being hydrolysed in this period. When a lower percentage of $\alpha$-amylase is encapsulated $(0.5 \%)$ the degradation rate is slower, but complete starch hydrolysis is reached after 8 weeks. Comparing the degradation profile of SPCL capsules in the presence of $\alpha$-amylase both free in solution and encapsulated, no significant differences are observed in either the weight loss or the concentration of reducing sugars.

The effect of enzyme degradation, in both the encapsulated and the free form, on the surface morphology of SPCL disks can be observed in the SEM micrographs shown in Figs. 5-8. Although the incubation in PBS also causes some erosion on the material surface (Figs. 5 and 6(A)), the incubation of the disks with the encapsulated $\alpha$-amylase leads to a highly porous structure. The degradation effect of the free enzyme (Fig. 8) is not as clear as the one observed with the encapsulated enzyme, which may be related with the starch distribution in the blend.

Enzyme hydrolytic activity induces changes in the physicochemical properties of the matrix and, as a result of degradation, the matrix collapses, as can be observed in Fig. 7(D).

\section{Discussion}

Previous studies about the thermal properties of the polymeric blend used in this work [46] showed that the melting peak of polycaprolactone fraction in the SPCL blend exhibited an onset temperature at $50.6^{\circ} \mathrm{C}$. Taking into account the low melting temperature of the SPCL blend, this material was selected to be used as the encapsulant matrix of a thermostable enzyme.
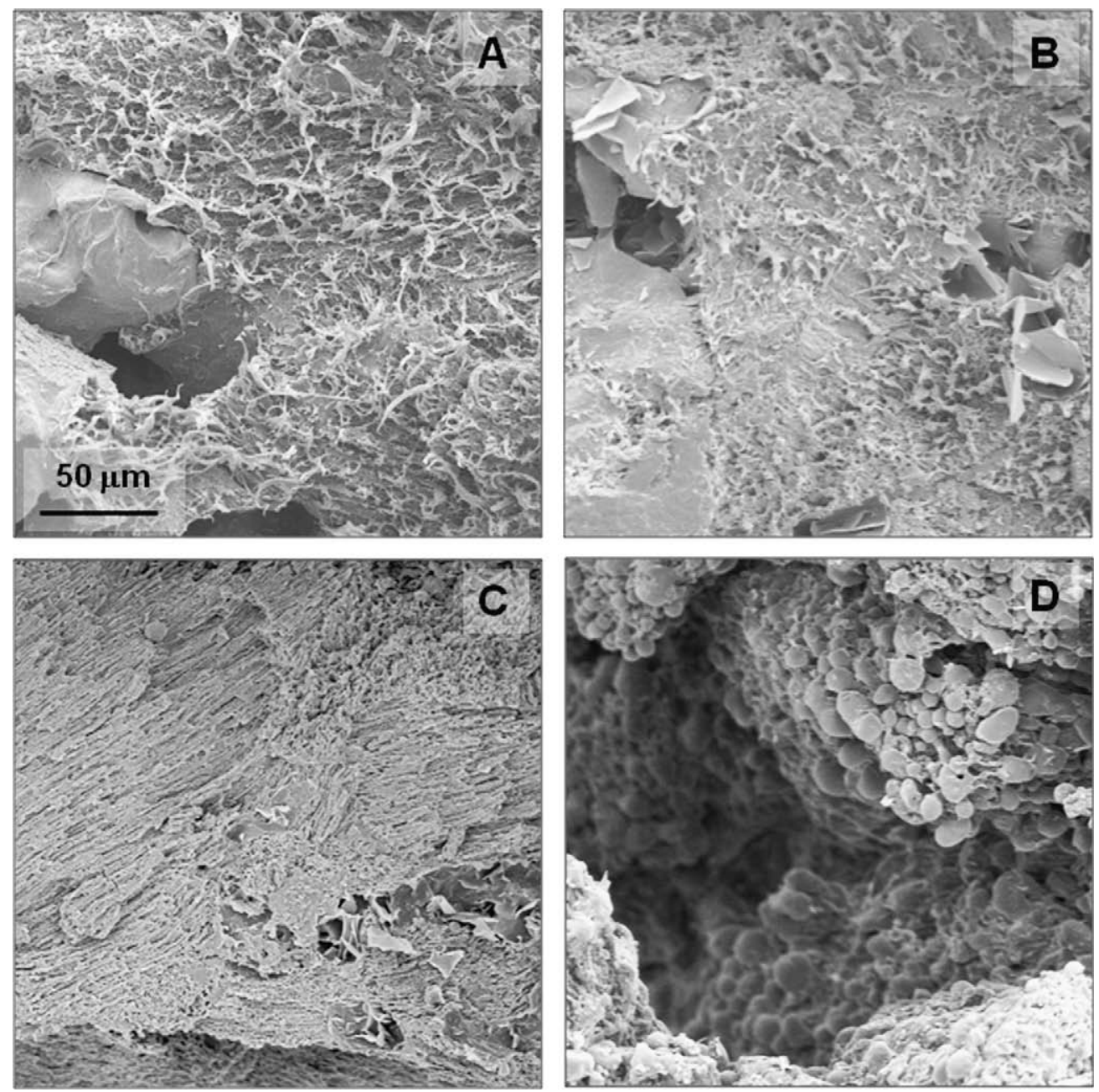

Fig. 7. SEM micrographs of the cross-section (cryogenic fractures) of SPCL disks before (A) and after degradation for 12 weeks in PBS (pH 7.4 ) at $37^{\circ} \mathrm{C}$. Control (B), with $0.5 \%(C)$ and $5 \%(D)$ encapsulated $\alpha$-amylase. 
It is known that enzyme activity depends on several factors, like temperature and water activity [50], and the rate of enzymatic reactions in insoluble substrates is limited by the rate at which the enzyme diffuses into the substrate. In the present study, it is important to minimize the enzyme activity during processing and storage but also to maintain its activity after the encapsulation process. By avoiding the use of water during processing, the water activity is kept low, minimizing the matrix degradation during this stage. Fig. 1 shows that when SPCL disks with encapsulated enzyme $(0.5 \%)$ were immersed in PBS at $4{ }^{\circ} \mathrm{C}$ the amount of sugars in the solution was negligible for a period of 4 weeks, thus indicating that the enzyme activity was minimized during the encapsulation process.

The reactivation of the enzyme can be achieved by enzymatic hydration upon water uptake of the solid substrate, which will act as a trigger for the degradation of the encapsulation matrix. After implantation, biomaterials interact with surrounding fluids by first absorbing water. The water uptake of the developed disks (with and without encapsulated enzyme) was determined at different temperatures and for various periods of time (Fig. 2). Water uptake increased with increasing temperature and also with increasing amounts of encapsulated enzyme (Fig. S1). Similar results were found by different authors $[14,21,22]$, who also observed differences in water uptake between matrices with and without encapsulated enzymes. In all the studies, matrices without encapsulated enzymes showed lower levels of water uptake. This phenomenon can be explained by the fact that, once small amounts of water penetrate the matrix, the enzyme is gradually dissolved and at the same time diffuses from the matrix, creating microscopic voids and leading to faster water penetration.

Water penetration will generate limited hydration and swelling of the SPCL disk, and once small amounts of water penetrate the matrix, $\alpha$-amylase dissolves gradually and its hydrolytic activity starts. The water uptake results shown in Fig. 2 B were obtained after 1 week at $37^{\circ} \mathrm{C}$. After this time, there is already significant degradation of the starch matrix for the disks with encapsulated enzyme (Fig. 4). The higher water uptake observed for the loaded disks might be due to the higher permeability of the matrix caused by degradation.

Proteins that are encapsulated into polymeric matrices can be denatured during the formulation, storage and release, which can result in loss of its activity. Release experiments were performed at $4{ }^{\circ} \mathrm{C}$ with loaded SPCL disks and the activity of the released enzyme was determined (Fig. 3). It was found that the enzyme activity reaches a plateau of $40 \%$ of its original activity by about $48 \mathrm{~h}$, after which no further increase is observed. The release rate at $4{ }^{\circ} \mathrm{C}$ might, however, be limited, being controlled mainly by enzyme diffusion from the matrix. At $37^{\circ} \mathrm{C}$ the release rate is expected to be higher due to the effects of diffusion and degradation of the polymeric matrix.

In the presence of $\alpha$-amylase (encapsulated or free in solution), the SPCL disks are degraded into water-soluble sugars, resulting in disk weight loss (Fig. 4). The degradation of SPCL disks was shown to be dependent on the
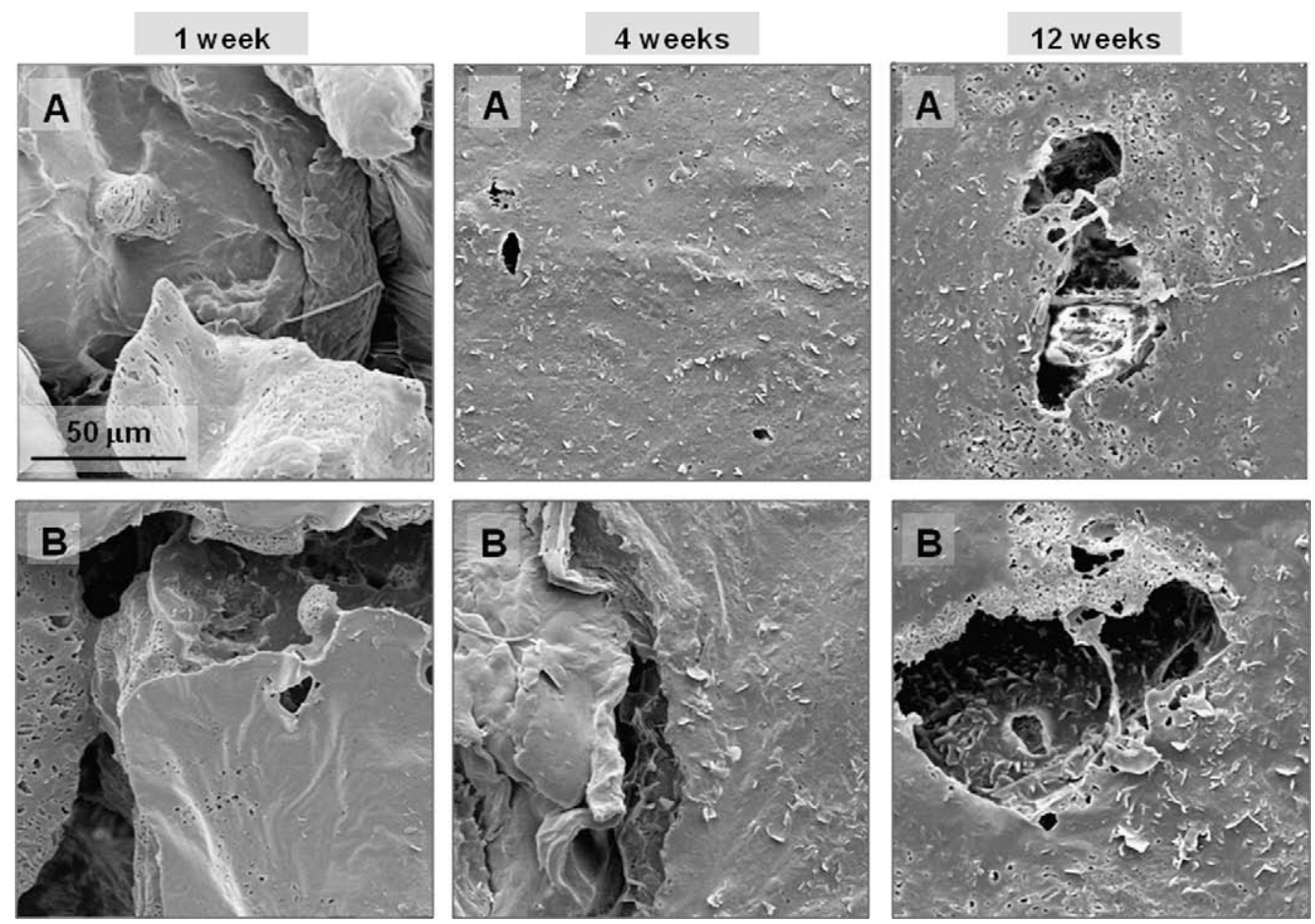

Fig. 8. SEM micrographs of the surface of SPCL disks after degradation for 1,4 and 12 weeks in PBS containing $0.5 \%$ (A) and $5 \%$ (B) $\alpha$-amylase free in solution. 
amount of enzyme encapsulated, being faster for disks with higher amount of enzyme. These results indicate that the degradation rate of the starch matrix can be controlled by the amount of encapsulated $\alpha$-amylase. The encapsulation method therefore seems to be adequate for controlling the degradation kinetics of starch-based biomaterials. The absence of sugars in solution for the control samples (disk without enzyme) for periods of time of up to 12 weeks also shows that there was no thermodegradation of starch matrix during processing (Fig. 4A). Comparing the degradation pattern between encapsulated (Fig. 4A) and free enzyme (Fig. 4B), no significant differences were observed. This indicates that the enzyme did not lose its activity during the preparation of the disks, revealing a non-denaturing effect of the encapsulation technique on the enzyme activity. The similarity in the degradation patterns of the free and encapsulated enzymes might indicate that after 1 week the encapsulated enzyme has been completely released from the SPCL disk; the results of weight loss and concentration of the reducing sugars would thus be comparable to those obtained for the enzyme free in solution. However, the SEM images show a distinct degradation effect between the encapsulated (Fig. 6) and free enzyme (Fig. 8). The disks containing $\alpha$-amylase entrap active enzyme in a limited space and thus the accessible reacting surface of the starch matrix per enzyme is higher that when the enzyme is free in solution. In the latter case, only a part of the active enzyme is in contact with the external surface of the matrix and it cannot penetrate more deeply in the disk.

\section{Conclusions}

This study investigated the potential of a novel approach to control the degradation kinetics of a starchbased biomaterial by encapsulating a starch-degrading enzyme into the starch matrix using a thermomechanical process. The results showed that by using a thermostable enzyme it is possible to retain its activity during the encapsulation process, and the degradation of the starch matrix can be controlled by encapsulating the proper amount of $\alpha$ amylase. Although a microbial enzyme was used in this study, one must bear in mind that if implantation in the human body is envisioned, enzymes from human origin would be required to avoid an immune response. With the advances in genetic engineering, it should be possible to introduce internal thermostability in mesophilic enzymes (e.g. human enzymes), which might in the future allow the incorporation of human enzymes during the processing of biomaterials under moderately high temperatures.

\section{Acknowledgements}

This work was partially supported by Portuguese Foundation for Science and Technology (FCT) through funds from the POCTI and/or FEDER Programmes. This work was carried out under the scope of the European NoE EXPERTISSUES (NMP3-CT-2004-500283).

\section{Appendix A. Supplementary data}

Supplementary data associated with this article can be found, in the online version, at doi:10.1016/j.actbio.2009. 04.039 .

\section{References}

[1] Hanes J, Chiba M, Langer R. Degradation of porous poly(anhydrideco-imide) microspheres and implications for controlled macromolecule delivery. Biomaterials 1998;19(1-3):163-72.

[2] Suzuki M, Ikada Y. Biodegradable polymers in medicine. In: Reis RL, Román JS, editors. Biodegradable systems in tissue engineering and regenerative medicine. Boca Raton, FL: CRC Press; 2005. p. $3-12$.

[3] Hubbell JA. Biomaterials in tissue engineering. Bio-technology 1995;13(6):565-76.

[4] Hubbell JA. Synthetic biodegradable polymers for tissue engineering and drug delivery. Curr Opin Solid State Mater Sci 1998;3(3): $246-51$.

[5] Okada M. Chemical syntheses of biodegradable polymers. Prog Polym Sci 2002;27(1):87-133.

[6] Yasin M, Tighe BJ. Strategies for the design of biodegradable polymer systems - manipulation of polyhydroxybutyrate-based materials. Plast Rubb Compos Process Appl 1993;19(1):15-27.

[7] Mi FL, Tan YC, Liang HC, Huang RN, Sung HW. In vitro evaluation of a chitosan membrane cross-linked with genipin. J Biomater Sci Polym Ed 2001;12(8):835-50.

[8] Shalaby WSW, Park K. Chemical modification of proteins and polysaccharides and its effect on enzyme-catalyzed degradation. In: Shalaby SW, editor. Biomedical polymers. Designed-to-degrade systems. Munich: Hanser Publishers; 1994. p. 213-58.

[9] Tang YW, Santerre JP, Labow RS, Taylor DG. Use of surfacemodifying macromolecules to enhance the biostability of segmented polyurethanes. J Biomed Mater Res 1997;35(3):371-81.

[10] Tang YW, Santerre JP, Labow RS, Taylor DG. Application of macromolecular additives to reduce the hydrolytic degradation of polyurethanes by lysosomal enzymes. Biomaterials 1997;18(1):37-45.

[11] Agrawal CM, Athanasiou KA. Technique to control pH in vicinity of biodegrading PLA-PGA implants. J Biomed Mater Res 1997;38(2):105-14.

[12] Birnbaum DT, Brannon-Peppas L. Molecular weight distribution changes during degradation and release of PLGA nanoparticles containing epirubicin $\mathrm{HCl}$. J Biomater Sci Polym Ed 2003;14(1):87-102.

[13] Tracy MA, Ward KL, Firouzabadian L, Wang Y, Dong N, Qian R, et al. Factors affecting the degradation rate of poly(lactide-coglycolide) microspheres in vivo and in vitro. Biomaterials 1999;20(11):1057-62.

[14] Goldbart R, Traitel T, Lapidot SA, Kost J. Enzymatically controlled responsive drug delivery systems. Polym Adv Technol 2002;13(10-12): $1006-18$.

[15] Kamimura W, Ooya T, Yui N. Transience in polyion complexation between nicotinamide-modified dextran and carboxymethyl dextran during enzymatic degradation of dextran. J Biomater Sci Polym Ed 2001;12(10):1109-22.

[16] Lutolf MP, Lauer-Fields JL, Schmoekel HG, Metters AT, Weber FE, Fields GB, et al. Synthetic matrix metalloproteinase-sensitive hydrogels for the conduction of tissue regeneration: engineering cellinvasion characteristics. Proc Nat Acad Sci USA 2003;100(9):5413-8.

[17] Lutolf MP, Raeber GP, Zisch AH, Tirelli N, Hubbell JA. Cellresponsive synthetic hydrogels. Adv Mater 2003;15(11):888-92.

[18] West JL, Hubbell JA. Polymeric biomaterials with degradation sites for proteases involved in cell migration. Macromolecules 1999;32(1):241-4.

[19] Voet D, Voet JG, Pratt CW. Fundamentals of biochemistry. New York: John Wiley \& Sons Inc.; 1999. 
[20] Reslow M, Jönsson M, Laakso T. Sustained-release of human growth hormone from PLG-coated starch microspheres. Drug Deliv Syst Sci December 2002/January 2003; 2(4): 103-9.

[21] Yilmaz G, Ongen G, Jongboom ROJ, Feil H, van Dijk C, Hennink WE. Modulated release of a volatile compound from starch matrixes via enzymatically controlled degradation. Biomacromolecules 2002;3(2):305-11.

[22] Ongen G, Yilmaz G, Jongboom ROJ, Feil H. Encapsulation of alpha-amylase in a starch matrix. Carbohydr Polym 2002;50(1):1-5.

[23] Rahmouni M, Chouinard F, Nekka F, Lenaerts V, Leroux JC. Enzymatic degradation of cross-linked high amylose starch tablets and its effect on in vitro release of sodium diclofenac. Eur J Pharm Biopharm 2001;51(3):191-8.

[24] Dumoulin Y, Cartilier LH, Mateescu MA. Cross-linked amylose tablets containing alpha-amylase: an enzymatically-controlled drug release system. J Control Release 1999;60(2-3):161-7.

[25] Tuovinen L, Peltonen S, Liikola M, Hotakainen M, LahtelaKakkonen M, Poso A, et al. Drug release from starch-acetate microparticles and films with and without incorporated alphaamylase. Biomaterials 2004;25(18):4355-62.

[26] Vikman M, Hulleman SHD, Van der Zee M, Myllarinen P, Feil H. Morphology and enzymatic degradation of thermoplastic starchpolycaprolactone blends. J Appl Polym Sci 1999;74(11):2594-604.

[27] Ishiaku US, Pang KW, Lee WS, Ishak ZAM. Mechanical properties and enzymic degradation of thermoplastic and granular sago starch filled poly(epsilon-caprolactone). Eur Polym J 2002;38(2): 393-401.

[28] Schwach E, Averous L. Starch-based biodegradable blends: morphology and interface properties. Polym Int 2004;53(12):2115-24.

[29] Villar MA, Thomas EL, Armstrong RC. Rheological properties of thermoplastic starch and starch poly(ethylene-co-vinyl alcohol) blends. Polymer 1995;36(9):1869-76.

[30] Shin BY, Lee SI, Shin YS, Balakrishnan S, Narayan R. Rheological, mechanical and biodegradation studies on blends of thermoplastic starch and polycaprolactone. Polym Eng Sci 2004;44(8):1429-38.

[31] Bastioli C. Properties and applications of Mater-Bi starch-based materials. Polym Degrad Stabil 1998;59(1-3):263-72.

[32] Reis RL, Cunha AM, Allan PS, Bevis MJ. Mechanical behavior of injection-molded starch-based polymers. Polym Adv Technol 1996;7(10):784-90.

[33] Salgado AJ, Coutinho OP, Reis RL. Novel starch-based scaffolds for bone tissue engineering: cytotoxicity, cell culture, and protein expression. Tissue Eng 2004;10(3-4):465-74.

[34] Gomes ME, Ribeiro AS, Malafaya PB, Reis RL, Cunha AM. A new approach based on injection moulding to produce biodegradable starch-based polymeric scaffolds: morphology, mechanical and degradation behaviour. Biomaterials 2001;22(9):883-9.

[35] Gomes ME, Sikavitsas VI, Behravesh E, Reis RL, Mikos AG. Effect of flow perfusion on the osteogenic differentiation of bone marrow stromal cells cultured on starch-based three-dimensional scaffolds. J Biomed Mater Res A 2003;67A(1):87-95.

[36] Silva GA, Costa FJ, Neves NM, Coutinho OP, Dias ACP, Reis RL. Entrapment ability and release profile of corticosteroids from starchbased microparticles. J Biomed Mater Res A 2005;73A(2):234-43.

[37] Elvira C, Mano JF, San Roman J, Reis RL. Starch-based biodegradable hydrogels with potential biomedical applications as drug delivery systems. Biomaterials 2002;23(9):1955-66.

[38] Boesel LF, Azevedo HS, Reis RL. Incorporation of alpha-amylase enzyme and a bioactive filler into hydrophilic, partially degradable, and bioactive cements (HDBCs) as a new approach to tailor simultaneously their degradation and bioactive behavior. Biomacromolecules 2006;7(9):2600-9.

[39] Boesel LF, Fernandes MHV, Reis RL. The behavior of novel hydrophilic composite bone cements in simulated body fluids. J Biomed Mater Res B Appl Biomater 2004;70B(2):368-77.

[40] Azevedo HS, Gama FM, Reis RL. In vitro assessment of the enzymatic degradation of several starch based biomaterials. Biomacromolecules 2003;4(6):1703-12.

[41] Gomes ME, Azevedo HS, Moreira AR, Ella V, Kellomaki M, Reis RL. Starch-poly(epsilon-caprolactone) and starch-poly(lactic acid) fibre-mesh scaffolds for bone tissue engineering applications: structure, mechanical properties and degradation behaviour. J Tissue Eng Regen Med 2008;2(5):243-52.

[42] Bastioli C, Cerutti A, Guanella I, Romano GC, Tosin M. Physical state and biodegradation behavior of starch-polycaprolactone systems. J Environ Polym Degrad 1995;3(2):81-95.

[43] Bastioli C, Belloti V, Del Tredici G, Guanella I, Lombi R. Complexed starch-containing compositions having high mechanical properties. US Patent 6348524-B2; 2002.

[44] Bastioli C, Belloti V, Del Tredici G, Lombi R, Montino A, Ponti R. Biodegradable polymeric compositions based on starch and thermoplastic polymers. WO Patent 92/19680; 1992.

[45] Bastioli C, Belloti V, Del Tredici G, Lombi R, Montino A, Ponti R. Biodegradable polymeric compositions based on starch and thermoplastic polymers. European Patent 0539541 B1; 1997.

[46] Mano JF, Koniarova D, Reis RL. Thermal properties of thermoplastic starch/synthetic polymer blends with potential biomedical applicability. J Mater Sci Mater Med 2003;14(2):127-35.

[47] Pashkuleva I, Azevedo HS, Reis RL. Surface structural investigation of starch-based biomaterials. Macromol Biosci 2008;8(2):210-9.

[48] Ghose TK. Measurement of cellulase activities. Pure Appl Chem 1987;59:257-68.

[49] Sheppard NF, Madrid MY, Langer R. Polymer matrix controlled release systems - influence of polymer carrier and temperature on water-uptake and protein release. J Appl Polym Sci 1992;46(1):19-26.

[50] Bell G, Halling PJ, Moore BD, Partridge J, Rees DG. Biocatalyst behaviour in low-water systems. Trends Biotechnol 1995;13(11): 468-73. 